\title{
RESEARCH ON THE MANAGEMENT SKILLS AND ABILITIES ACQUIRED IN THE MILITARY EDUCATION SYSTEM
}

\author{
Venelin Terziev, ${ }^{1}$ Nikolay Nichev ${ }^{2}$
}

\begin{abstract}
The socio-economical changes in the Bulgarian society leave their traces in all spheres of public life and in the military education system in particular. The implemented reforms in the Republic of Bulgaria assign to military higher schools the task to train officers with management skills and abilities at a higher level, ready to solve efficiently complicated and versatile tasks. The specific character of the non-combatant officer's activity, sets increased requirements to their training and assurance of its effectiveness. The non-combatant cadet's management skills and abilities appear to be significant indicators of improving the effectiveness in the military professional training for management activity and developing a readiness for the timely taking of quality management decisions. The research target is the professional military training of the future logistic officers. The research aim is to analyze the acquired skills and abilities in the course of professional military training management and to related to them management effectiveness. The methods of research are: theoretical analyses of the military education literature, inquiry, statistics, substantiation and general conclusions.
\end{abstract}

JEL Classification Numbers: I21, I23, M53; DOI: http://dx.doi.org/10.12955/cbup.v5.1036

UDC Classification: 378

Keywords: military training, training of cadets

\section{Introduction}

Contemporary challenges in the system of higher education has led to significant reforms in the educational system in the Republic of Bulgaria. The military education system is not exempt from these changes and the training of officers targeted to the application into practice of the acquired knowledge and skills and to strive constantly for perfection of their professional skills is a topical question. The specific character of the non-combatant officer's activity, sets increased requirements to their management skills and abilities, especially concerning decision taking and management activities.

The management abilities can be inborn or acquired. Logical thinking, the power of observation, concentration ability, perception power and communication skills are inborn abilities. The acquired abilities are: determination, dynamics, reliability, responsibility, persistency, self-confidence, and accuracy.

Quality is a category which describes the characteristics of a particular object. Nowadays this is subjected to serious discussion in the social and economic sciences and is one of the basic concepts, upon which a number of political, management and organizational theories are being grounded.

The ability is the possibility to succeed in a given task or undertaking, a way of self-dependent use of knowledge and concepts, intellectual processes and physical activities for the solution of theoretical and practical tasks.

Management abilities are a combination of the following: meaningful abilities - to perform a certain profession successfully and to contribute to the implementation of a specific activity; competencies for team work, including the skills to communicate, in order to solve different kinds of conflicts; conceptual competences - ability to foresee the future development of the organization and to take the correct strategic decisions; abilities to diagnose and analyse the problems, which creates possibilities to work out various alternatives in decision making; and management competencies.

The management activity of the logistics officer of the troops, compared to the commanders of fighting formations, is more versatile and has peculiarities, which must be taken into consideration in the training process of future logistic officers for the implementation of their professional military activity.

\footnotetext{
${ }^{1}$ Vasil Levski National Military University, Veliko Tarnovo, Bulgaria; University of Rousse, Rousse, Bulgaria; University of Telecommunications and Post, Bulgaria, terziev@skmat.com

${ }^{2}$ Vasil Levski National Military University, Veliko Tarnovo, Bulgaria, nicheff@abv.bg
} 


\section{Material and methods}

The research work was carried out in the Land Forces Faculty of the Vasil Levski National Military University during the period 2014 - 2016. The research embraces cadets from the specialties "Organization and management of the tactical subdivisions for logistical support" with specializations "Non-combatant troops and fuel and lubrication materials" (FLM) and "Movement and transport"; "Organization and management of the military formations on a tactical level" with specialization "Material resources, movement and transport". The examined group consists of 49 people, separated into the following subgroups (SG): SG1 - 9 Cadets, SG2 - 6 Cadets, SG3 - 7 Cadets, SG4 - 7 Cadets, SG5 11 Cadets, SG6 - 9 Cadets (Table 1).

\begin{tabular}{|c|c|c|c|c|}
\hline $\begin{array}{l}\text { Sub- } \\
\text { group }\end{array}$ & Military specialization & Year of training & Curriculum & $\begin{array}{l}\text { Number of } \\
\text { students }\end{array}$ \\
\hline 1 & Non-combatant troops and FLM & $5^{\text {th }}$ & 07 & 9 \\
\hline 2 & Movement and transport & $5^{\text {th }}$ & 07 & 6 \\
\hline 3 & Non-combatant troops and FLM & $4^{\text {th }}$ & 07 & 7 \\
\hline 4 & $\begin{array}{l}\text { Material resources, movement and } \\
\text { transport }\end{array}$ & second & 12 & 7 \\
\hline 5 & $\begin{array}{l}\text { Material resources, movement and } \\
\text { transport }\end{array}$ & third & 12 & 9 \\
\hline 6 & $\begin{array}{l}\text { Material resources, movement and } \\
\text { transport }\end{array}$ & second & 12 & 11 \\
\hline
\end{tabular}

Source: Authors

The research was carried out in three stages:

- First stage - examination of the literature and selection of the research methodology;

- Second stage - The study was conducted. The empirical information was collected using the inquiry method in the format of a direct group questionnaire, comprising all the members of the examined community;

- Third stage - analysis of the obtained results and the drawing of conclusions.

A methodology for the identification of the personally possessed management competences, their abilities, and the grade of their display was used in the research. The methodology comprised 50 questions, each of them having two possible answers to choose from. Having analyzed the given answers of the examined people, a conclusion is drawn whether they possess the required personal competencies and the skills of a good manager. In accordance with the given key, the total sum of the obtained points is determined. For the evaluation, the following points result is used:

- up to 25 points - incomplete and less pronounced management competencies and skills;

- from 26 up to 35 points - well expressed management competencies and skills;

- from 36 up to 40 points - highly expressed management competencies and skills;

- more than 40 points - authoritarian management style.

\section{Results}

The results of the conducted research show that a large part of the examined people demonstrate incomplete or less expressed management competences and skills $-26.5 \%$. The fact, which is disturbing, is that only $8.2 \%$ of the cadets possess highly expressed management competences and skills. The main task of the education and training process in the Vasil Levski National Military University is to increase the share of cadets with well or highly expressed management competences and skills. $65.3 \%$ of all respondents have shown such competences and skills. The results of the conducted research are shown in Table 2. The percentage of the levels of management competences and skills of the whole group is illustrated in Figure 1. The formation of well and highly expressed management abilities and skills in the students from different years of training in the Vasil Levski National Military University is illustrated in Figure 2. 


\begin{tabular}{|l|c|c|c|c|c|c|}
\hline \multicolumn{2}{|l|}{ Table 2: Levels of management competencies and skills in the examined subgroups } \\
\hline \multicolumn{1}{|c|}{ Subgroup } & SG 1 & SG 2 & SG 3 & SG 4 & SG 5 & SG 6 \\
$\begin{array}{l}\text { Levels of } \\
\text { management competencies and skills }\end{array}$ & & & & & & \\
\hline incomplete and less expressed & 2 & 2 & 2 & 1 & 3 & 3 \\
\hline well expressed & 1 & 3 & 5 & 6 & 6 & 4 \\
\hline highly expressed & 2 & 1 & & & & 1 \\
\hline authoritarian style & & & & & & \\
\hline Source: Authors
\end{tabular}

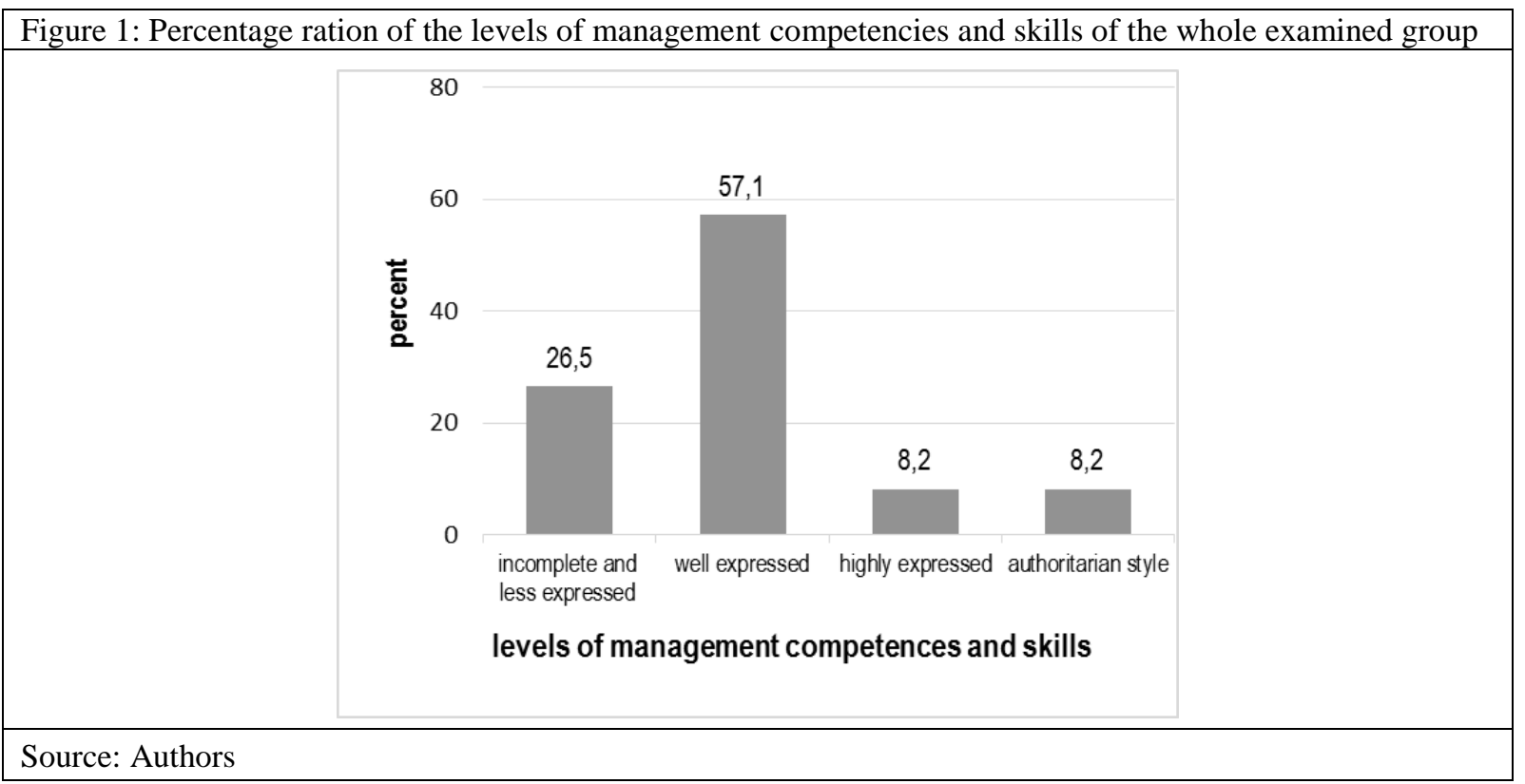

Figure 2: Results from the examined well and highly expressed management competencies and skills according to curriculum and years of training

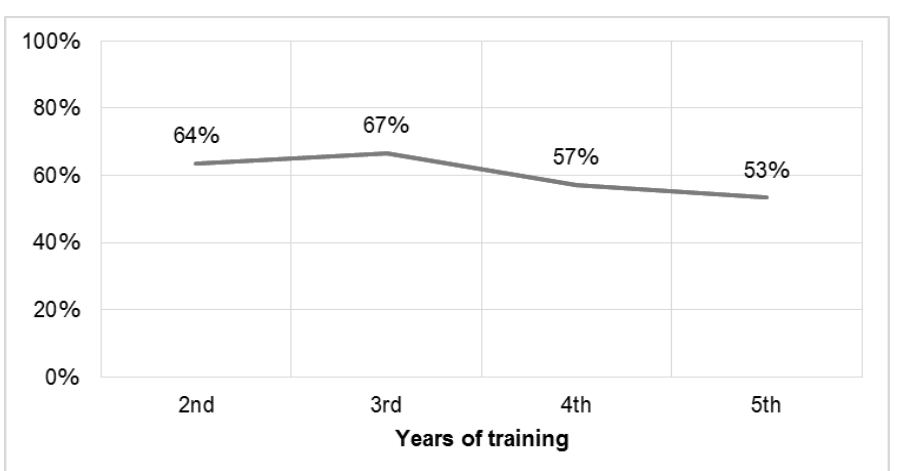

Source: Authors

The results show that the decrease of the highly expressed management competencies and skills of cadets during their fifth year of training is compensated by the increase of the share $(17 \%)$ of the authoritarian style of management.

As a general regularity of all examined sub-groups is the high share of the incomplete and less expressed management competencies and skills. Most probably this fact is due to the preferred subjects for general military and technical training of the military specialty and due to training subjects with emphasized logistic themes and the learning of a smaller number of management disciplines during the civilian specialization. 


\section{Discussion}

Effectiveness in its common meaning shows the relation of the achieved result to the goal. Effectiveness is connected with the expedience of the activity. The higher the grade of achievement of a goal is, the more effective the activities and undertakings are. According to the Bulgarian legislation, effectiveness is defined as the grade of achievement of a goal, comparing the real and the expected results of the activity. Management effectiveness is the degree of achievement by the manager in the organization implementation of the set-up targets and the solution of related tasks. Management effectiveness is directly connected with the availability of certain management competences and skills. Independence is a cognitive and volitional property, where the ability of the person to plan, systemize, regulate and actively perform his/her own activity, based on a personal life experience, is formed knowledge in the form of ideas and notions, skills, convictions and habits without any management or direct practical assistance from other persons.

The methodology of Vasiliy Pugachev was used in the Research of Management Effectiveness (Pugachev, 2003). The methodology doesn't evaluate the management skills of an individual, but his/her practical activity in the role of the manager, as well as management style. The examined person replied to 40 questions choosing form the answers "yes" or "no," getting one point for each "yes" and zero points for each negative answer. The results of the performed research of the management style of the examined cadets are shown in Table 3.

\begin{tabular}{|l|c|c|c|c|c|c|}
\hline \multicolumn{2}{|c|}{ Table 3: Management style of the examined sub-groups } \\
\hline \multicolumn{1}{|c|}{ Subgroup } & SG 1 & SG 2 & SG 3 & SG 4 & SG 5 & SG 6 \\
Management style & & & & & & \\
\hline Highly effective & 7 & 6 & 3 & 6 & 6 & 3 \\
\hline Medium effective & 2 & - & 4 & 1 & 3 & 8 \\
\hline Less effective & - & - & - & - & - & - \\
\hline
\end{tabular}

Source: Authors

The percentage of the management style of the whole examined group is shown in Figure 3. The answers of the responding cadets from all years of training show, that $73 \%$ of the students have a highly effective management style, while $27 \%$ possess a medium effective one. A good indicator is the absence of students with a less effective management style. The forming of a highly effective management style in the students from different education years in the Vasil Levski National Military University and its development tendency are shown in Figure 4. The analysis of the management competencies and skills shows that the existing system for professional training of the future noncombatant officers allows the formation of appropriate management abilities and skills in the students. It is necessary to direct the efforts of the academic staff at the elaboration of the obtained abilities of the cadets from the specialty "Organization and management of military formations at a tactical level" and the military specialization "Material resources, movement and transport."

\begin{tabular}{|l|l|}
\hline Figure 3: Management style of the examined cadets \\
\hline Less effective; \\
\hline Source: Authors effective; \\
\hline
\end{tabular}




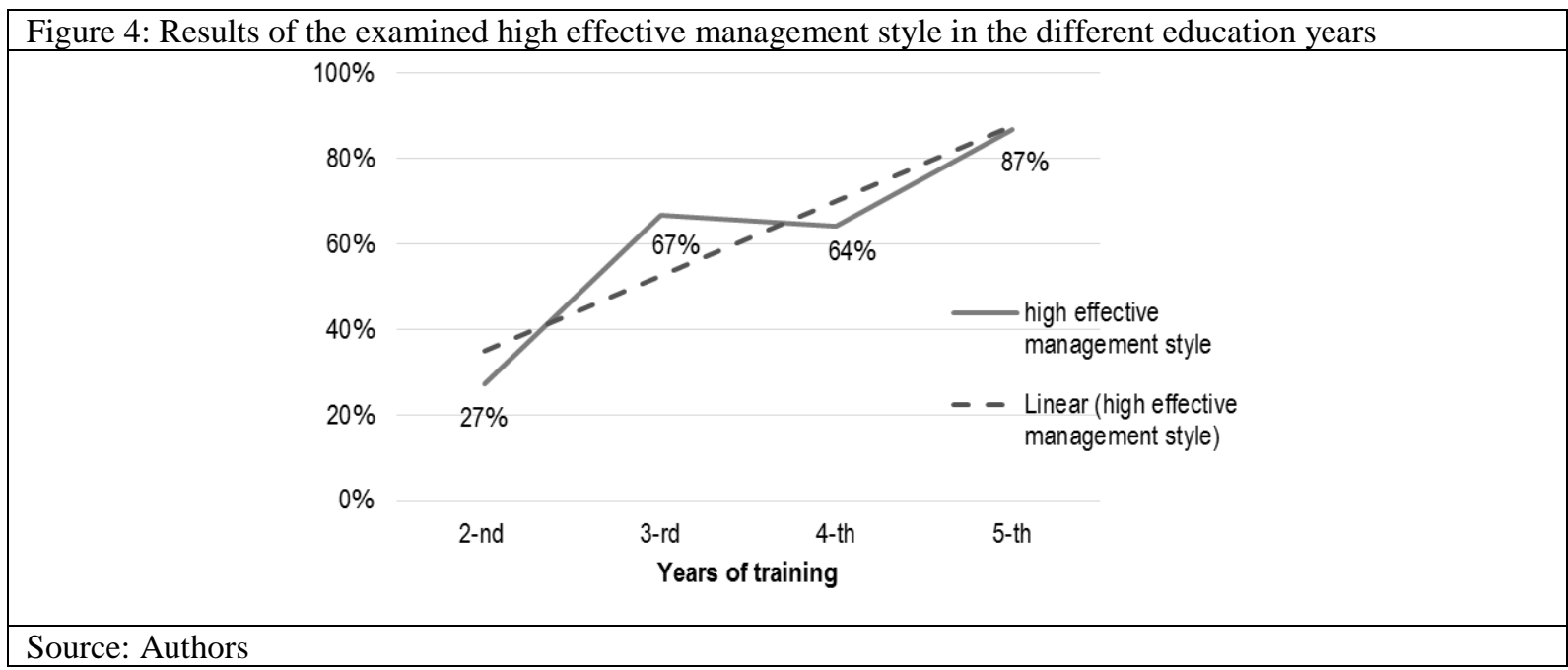

\section{Conclusion}

The training of future con-combatant officers for management activity is an integral part of professional military education and is carried out during the whole period of their training. It must take into consideration the specifics of the professional military activity of the future logistic officers. The acquisition of management competencies and skills in the cadets during their professional military training is predetermined by many factors, among which an important place is occupied by the obtaining of knowledge of the management competencies and skills in the process of the professional military training and by the stimulating of the practical training for the improvement of the management effectiveness in order to meet the requirement of the first logistic officer position. It is advisable to direct the efforts of the educative work towards the developing of the obtained management abilities paying special attention to the following competencies: determination, responsibility, persistency, self-confidence and accuracy.

\section{References}

Dictionary of Psychology. (1999). Bulgarica Publisher.

Pougachev, V.P. (2003). Tests, role-playing games, trainings at the personnel command; education for high schools students. Aspect Press Publisher. 